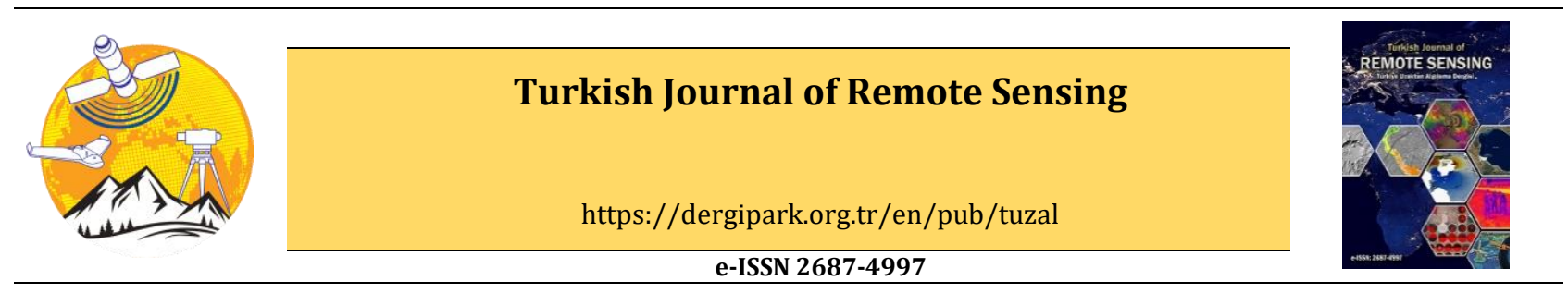

\title{
Detection of Archaeological Sites Using Remote Sensing in The Cilicia Pedias
}

\author{
Faris Demir*1(i) \\ ${ }^{1}$ Osmaniye Korkut Ata University, Faculty of Arts and Sciences, Department of Archaeology, Osmaniye, Turkiye
}

\author{
Keywords \\ Remote sensing \\ Archaeological Site \\ Detection \\ Landsat 7 ETM+ \\ Cilicia Pedias
}

\begin{abstract}
Ceyhan Plain is located at the southern of Turkey within the borders of Adana. This region as known as Cilicia Pedias in the ancient period. There are many lost and undiscovered ancient sites in Cilicia Pedias. At 3, 4 and 5 spectral bands of Landsat 7 image, it was determined that the archeological sites yield different spectral reflection values from other surface vegetation close to the modern settlement areas. Especially at near-infrared 4th band image, subsurface and surface ancient sites were determined. The unsupervised classification, Histogram Equalization and Principal Component Analysis methods were used with Image analysis 4, 3, 2 band combination. It was determined that the ancient sites may be distinguished from the modern settlement areas with Principal Component Analysis and linear method. The one of which the resolution is higher in the visual perception was used in 8th band imagery enhancement procedure. Also by using Spot and Aster images, the distribution and spatial features of sites were analyzed. In this paper, 42 units' unknown ancient sites were determined except for the sites which had been known but got lost due to the destructing.
\end{abstract}

\section{Kilikya Pedias'ta Uzaktan Algılama Kullanılarak Arkeolojik Yerleşim Tespiti}

\author{
Anahtar Kelimeler: \\ Uzaktan Algilama \\ Arkeolojik Yerleşim \\ Tespiti \\ Landsat 7 ETM+ \\ Kilikya Pedias
}

\begin{abstract}
ÖZ
Ceyhan Ovası, Türkiye'nin güneyinde Adana sınırları içerisinde yer almaktadır. Bu bölge antik dönemde Kilikya Pedias olarak bilinmektedir. Kilikya Pedias'ta kaybolan ve keşfedilmeyen birçok antik yerleşim bulunmaktadır. Landsat 7 görüntüsünün 3, 4 ve 5 spektral bantlarında, arkeolojik alanların modern yerleşim alanlarına yakın diğer yüzey bitki örtüsünden farklı spektral yansıma değerleri verdiği tespit edilmiştir. Özellikle yakın kızılötesi 4 . bant görüntüsünde yer altındaki ve yüzeydeki antik yerleşimler belirlenebilmiştir. Görüntü analizinde 4, 3, 2 bant kombinasyonları ile Eğitimsiz Sınıflandırma, Histogram Eșitleme ve Temel Bileșen Analizi yöntemleri kullanılmıştır. Temel Bileșen Analizi ve doğrusal yöntem ile antik yerleșimlerin modern yerleșim alanlarından ayrılabileceği tespit edilmiştir. Görsel algılamada çözünürlüğü daha yüksek olan 8. bant görüntü zenginleștirme işleminde kullanılmıștır. Ayrıca Spot ve Aster görüntüleri kullanılarak yerleşimlerin dağılımı ve mekânsal özellikleri analiz edilmiştir. $\mathrm{Bu}$ makalede bilinen ancak tahrip nedeniyle kaybolan antik yerleșimler dișında 42 bilinmeyen antik yerleşim tespit edilmiştir.
\end{abstract}

* Corresponding Author
*(farisdemir@gmail.com) ORCID ID 0000-0001-8370-4350

Research Article / DOI: 10.51489/tuzal.904699 


\section{INTRODUCTION}

Ceyhan Plain is located at the southern of Turkey within the borders of Adana. Ceyhan Plain which is located at a strategically significant location has become the center of interest of various cultures as of prehistorical periods, and this region as known as Cilicia Pedias in the Ancient Period. Cilicia Pedias is surrounded by high mountain ranges, Taurus Mountains to the north and west, Amanus Mountains to the east and the southern Mediterranean. There are many lost and undiscovered ancient sites in Cilicia Pedias. Ancient sites in this region are of small size, and there are ceramics, adobe and stone materials subsurface and on the surface. Especially the ceramics, which are among the archaeological materials belonging to the sites, have spread over wide areas due to destruction and agricultural activities. The scale of the map showing the ancient sites found during the survey conducted in this region by Seton-Williams (1954) was insufficient in determining the location (Figure 1). It is also unknown how many archaeological sites remain undiscovered in Cilicia Pedias.
Remote sensing is playing an increasingly important role in the detection and documentation of ancient sites (Corrie, 2011). It is known that the archaeological remains, especially ceramic, stone and adobe materials, which have less permeability than their surroundings and retain heat, give a different reflection value than the soil reflection (Lillesand \& Kiefer, 2000; Etaya et al., 2000). These different heat properties can be used as a valuable tool for detecting ancient sites. Passive optical remote sensing technologies are effective tools to detect the presence of buried archaeological remains (Lasaponara \& Masini, 2013). Remote sensing technology can perceive the spectral characteristics of objects on ground and from a short distance beneath the surface (1-2m) (Kvamme, 2005). The aim of this study is to determine the spectral features of sites which were stayed under the alluvium in the bottom land and destructed by being graded by using the satellite images and to determine the locations of these settlements.

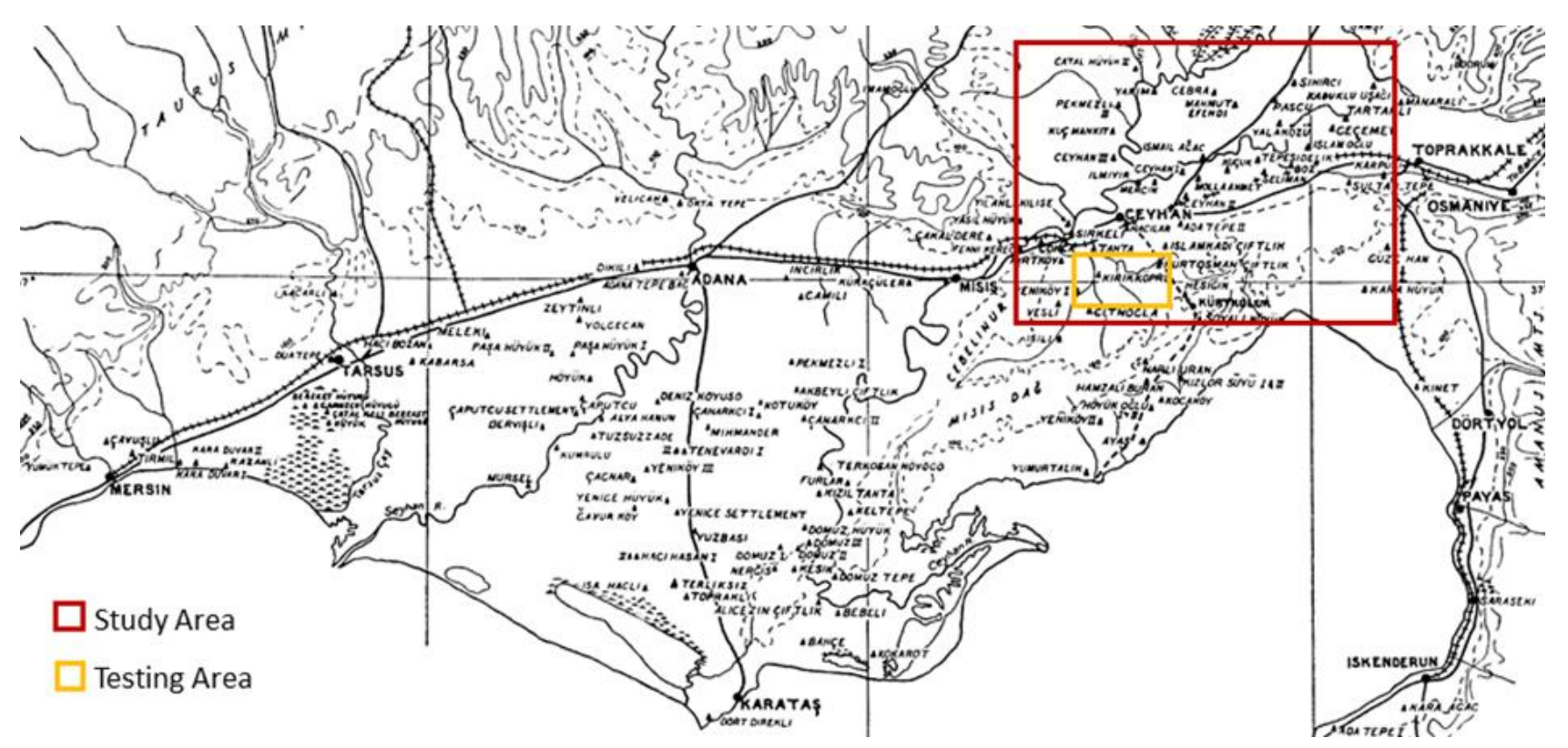

Figure 1. Sites and study area surveyed in 1951 (Seton-Williams, 1954: Figure 1).

The majority of archaeological remote sensing work in the Asia Minor and Middle East has been limited to detecting sites using the visible area of the electromagnetic (EM) spectrum, often neglecting a satellite's full multispectral capabilities (Drzewiecki, 2008; Corrie, 2011; Fiz et al., 2012;). This has usually involved simply enlarging high-resolution images by zooming into areas of interest to find sites and performing simple image processing procedures (Wilkinson, 2002; Ur, 2003; Beck, 2007; Corrie, 2011). The multispectral capability of satellite images can strongly improve the identification of differences in texture, moisture content, roughness, topography, various types of terrain, vegetation cover, lithological and geological composition and other information used in archaeological studies (Lasaponara \& Masini, 2013).

Many remote sensing studies used to the archaeology are the studies used to determination of large archaeological settlements by mainly using the radar (SAR, LIDAR) (Parcak, 2007; Chase et al., 2012; Fernandez-Diaz, 2014; Opitz et al., 2015; Golden et al., 2016). The sites in Cilicia Pedias are mainly small scale and they covered with less permeable claysized soil. 


\section{MATERIALS AND METHODS}

In this paper, Landsat 7 ETM+, Spot and Aster images and Erdas Imagine software were used. The approximate positions of sites that Seton-Williams (1954) identified in his research in Cilicia Pedias and satellite images covering this area were transferred to Geographical Information System (GIS) database.

A small test area was selected in the study area in order to determine the spatial and spectral features of sites at optimum level and maximize the determination level. This test area was selected in the way that it would cover three of sites which were determined by Seton-Williams (1954). In the image analysis, band combination, unsupervised classification, contrast enhancement and principal component analysis method were used. In the visual interpretation, the spatial features of sites were also comparatively investigated by using Spot and Aster images. The anomalies used in the research were documented with the help of GPS in the land.

\section{IMAGE ANALYSIS AND INTERPRETATION FOR DETERMINING ANCIENT SITES}

The main purpose of remote sensing is to detect changes in spectral reflectance values between the area of interest and its surroundings. The basis of any remote sensing study is the development of a research strategy that maximizes the chances of searching in high probability locations (Corrie, 2011). In order to determine archaeological sites there needs to be an understanding of how area is defined, and which spectral bands can be used to detect them. In Landsat 7-ETM+ image (Table 1), it is seen that the ancient sites have more reflection values in visible region bands 3, 2 and near-infrared (NIR) band 4 yield a reflection value different from other surface objects (Figure 2). For this reason, it was deemed appropriate to use 4, 3, 2 spectral bands and panchromatic band 8 with high resolution in image interpretation processes.

Table 1. Landsat 7 ETM+ specifications

\begin{tabular}{llll}
\hline Bands & & Wavelength & Resolution \\
\hline Band 1 & Blue & $0.441-00514$ & 30 \\
Band 2 & Green & $0.519-0.601$ & 30 \\
Band 3 & Red & $0.631-0.692$ & 30 \\
Band 4 & NIR & $0.772-0.898$ & 30 \\
Band 5 & SWIR-1 & $1.547-1.749$ & 30 \\
Band 6 & TIR & $10.31-12.36$ & 60 \\
Band 7 & SWIR-2 & $2.064-2.345$ & 30 \\
Band 8 & Pan & $0.515-0.896$ & 15 \\
\hline
\end{tabular}

According to Figure 2, the destructed and subsurface ancient sites give close reflection values. It is seen that the sites which have a specific elevation have a high reflection value. It is a presumable case that the sites of which material contents are dense may yield higher reflection value compared to the sites which are destructed and material content has been expanded to the wider areas. The sites do not show a homogeneous structure in order words their internal structures and geomorphological features differ from each other. It is a presumable case that they may yield close spectral values due to that the material content of sites is same with the content of modern settlements. There are adobe materials, ceramics, earthenware floors and roof tiles in the sites and modern settlements. There are modern settlements on some sites. As the geomorphological properties of sites are different from the properties of modern settlements, they may be determined with slight spectral variations in 3 , 4th (R, NIR) bands. Therefore, it will be a right approach to review both spectral and spatial properties in order to distinguish the ancient sites from modern settlements in a right way.

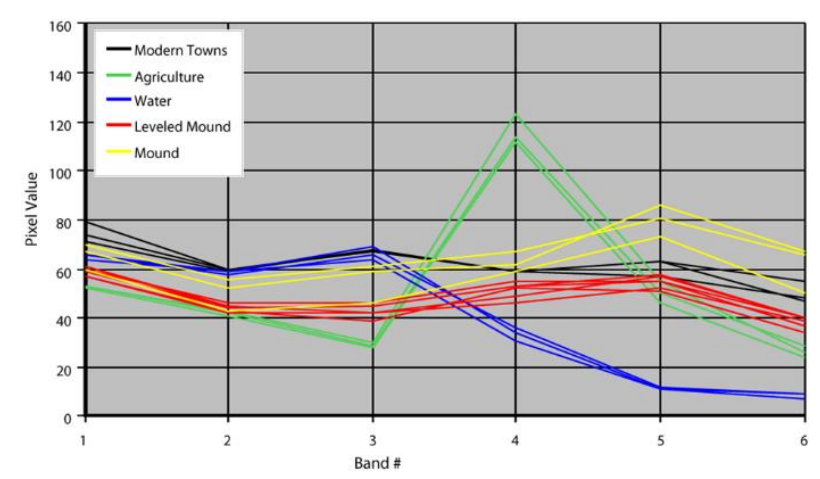

Figure 2. Spectral profiles of sites and several landscape features

The use of Landsat 7 ETM+ 4, 3, 2 (NIR, R, G) band combination and 8th panchromatic band of which resolution was high in imagery enhancement procedure gave positive results (Figure 3 ). The presence of materials such as dense ceramic, tile, adobe material and stone foundation in the structure of sites which are archeological settlements caused to different reflection values compared to their surroundings and created a contrast (Beck, 2007). In the visual perception, band 4 properties were effective on the determination of sites at the satellite image. These are varied in texture, shape, size, and tone, and ancient sites were easier to identify when at least two properties could be examined together. The ancient sites can be determined in the satellite images due to these properties.

The primary purpose of archaeological remote sensing is to detect changes in contrast between the area of interest and its surrounding matrix (Corrie, 2011). It was determined that the cereals were very rare especially in the destructed sites. This is resulted from the density of ceramic parts in the sites and the stone foundations. There is a direct proportion between the size of site and ceramic density. In a medium sized site, the reflection decreases as the density of ceramic increases. In the test area, there were sites which were not 
destructed, of which big part was destructed and there were modern buildings. Thus, the characteristic features of sites with different features in satellite images were examined and analysis methods that distinguish them from modern settlements were applied.

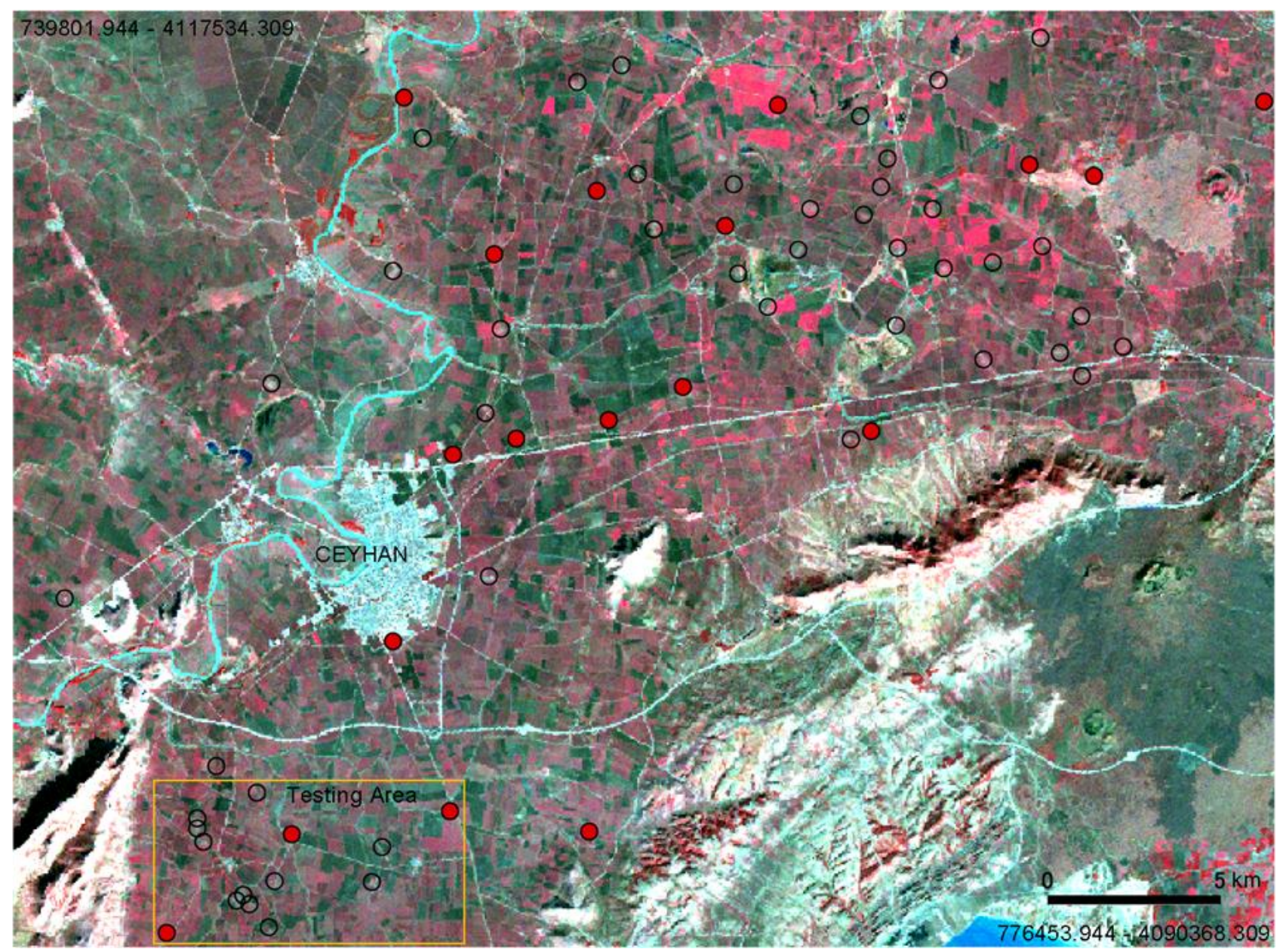

Figure 3. Study area with boxed testing area. Landsat 7 ETM+ 4, 3, 2 (NIR, R, G) band combination, Visually Enhanced Image. Sites known from an earlier survey are filled in red, while newly discovered sites are circled.

In the Landsat 7 ETM $+4,3,2$ (NIR, R, G) band combination, the sites are usually circular or elliptical and feature a radiant tone with a bright central portion and a lowering proximo-distally. The sites which were not destructed had a circular and very bright tone characteristic and a shade occurred at northern part due to elevation. The sites which were not destructed may be easily distinguished from the modern settlements and roads due to their very bright tones, sizes, circular shapes, textures and due to that they did not create a shade. The destructed sites can be easily distinguished due to their bright tones and brightness tones descending in the proximo-distal, sizes and shapes. In this area, 11 unit sites which show same anomaly properties were determined (Figure 4).

Image enhancement procedure interprets the data better and it is the procedure to turn the information in a more interpretable way. Digital image processing enhances the imagery to make it more interpretable. Using image enhancement methods in Landsat 7 satellite images, ancient sites have become more easily detectable. In contrast enhancement procedure (Jensen, 2005), Standard Deviation Contrast Stretch techniques among Histogram Equalization and Linear Contrast Stretch methods of Nonlinear Contrast Stretch methods were used. These techniques used in the visual perception made the sites more distinctive. Using Spot and Aster images, the distribution and spatial features of sites were analyzed. In the visual perception, the determinations obtained from Landsat 7 ETM+ image were also valid for Aster and Spot images of which resolution is high.

In the test area, 6 classes were selected with Landsat 7 ETM+ 4, 3, 2 (NIR, R, G) band combination and unsupervised classification was made (Figure 5). The sites may be visually distinguished from the land vegetation, modern settlement and roads. The sites are distinguished from the natural land vegetation in the spectral resolution analysis but take place within the same class with the modern settlements and roads. As stated before, the distinguish of spectral reflection value between the sites and modern settlements is very critical due to that the material contents are similar and same. 


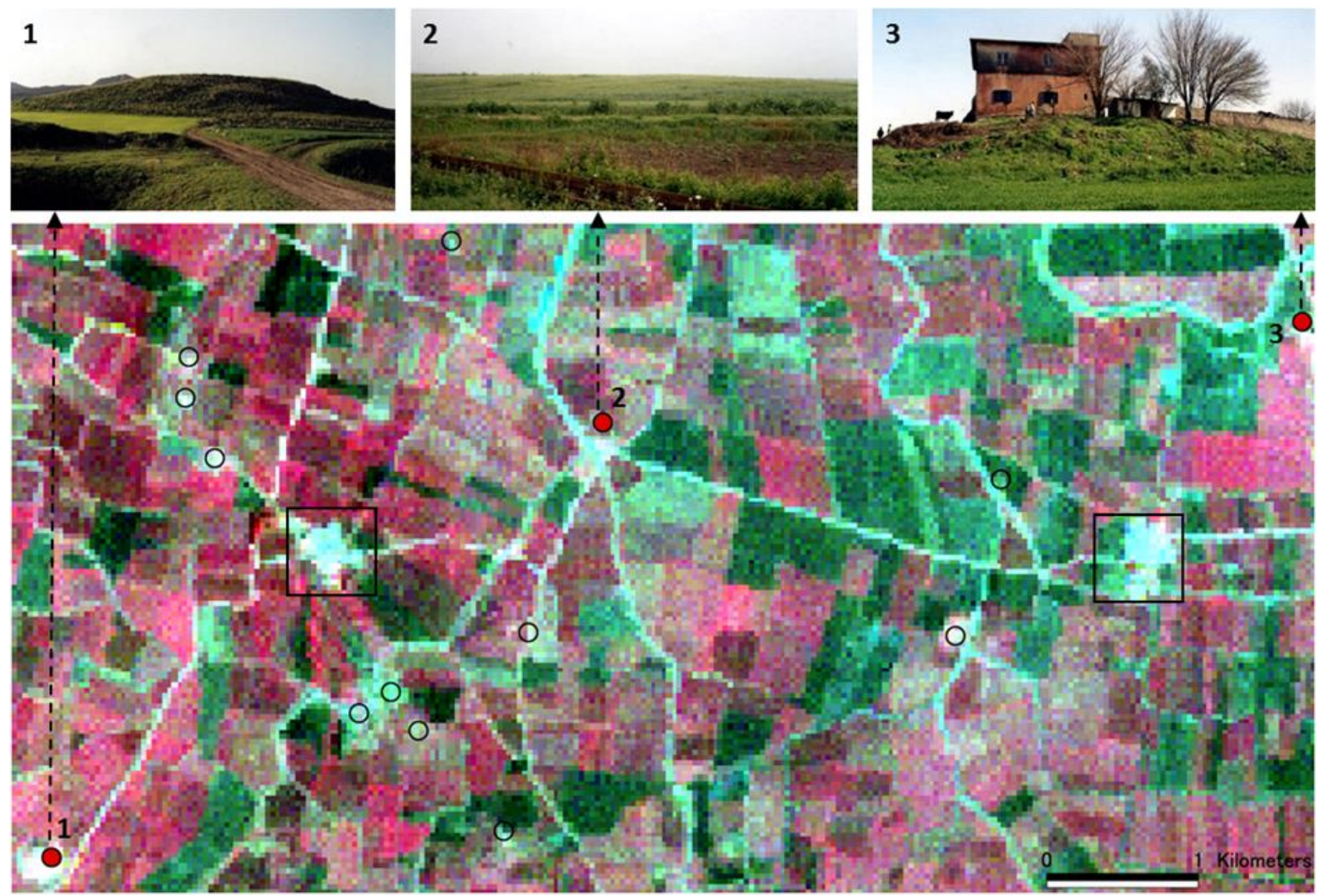

Figure 4. Testing area. Landsat $7 \mathrm{ETM}+4,3,2(\mathrm{NIR}, \mathrm{R}, \mathrm{G})$ band combination. Sites previously known from an earlier survey are filled in red, while newly discovered sites are circled. Modern settlements are squared.

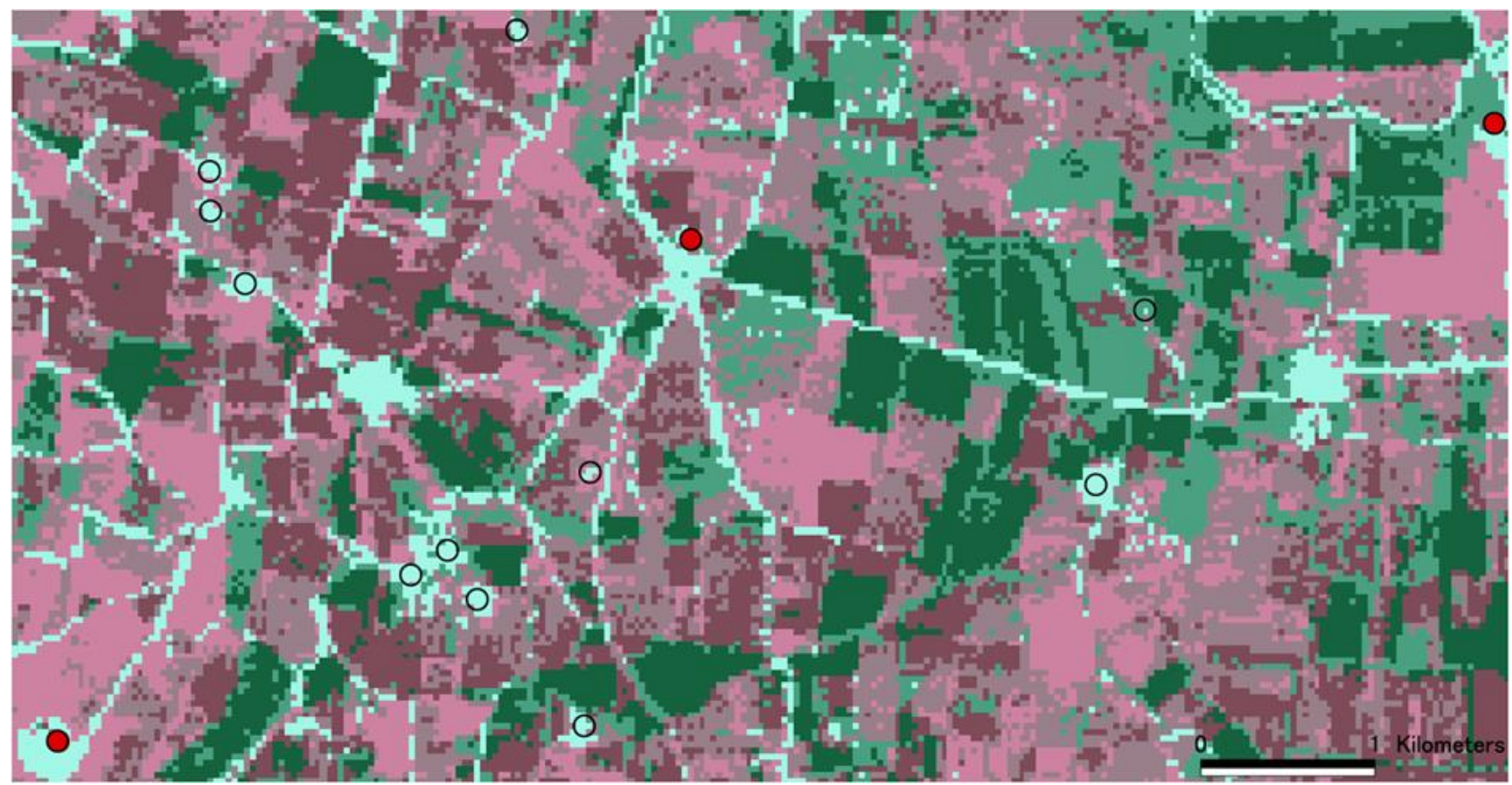

Figure 5. Testing area. Landsat 7 ETM+ 4, 3, 2 (NIR, R, G) band combination False Color Composites (FCC), Unsupervised Classification 6 class.

Principal Component Analysis is used for spectral pattern recognition as well as image enhancement (Kumar, 2004). With Principal Component Analysis method, the sites on which linear lookup was made were distinguished from the modern settlements and roads to a large extent. The modern settlements (boxed) and roads were displayed in red and green color; the sites were displayed in green color. In the site on which there was a modern structure, the modern structure was displayed in red color and site part was displayed in green color (Figure 6). 


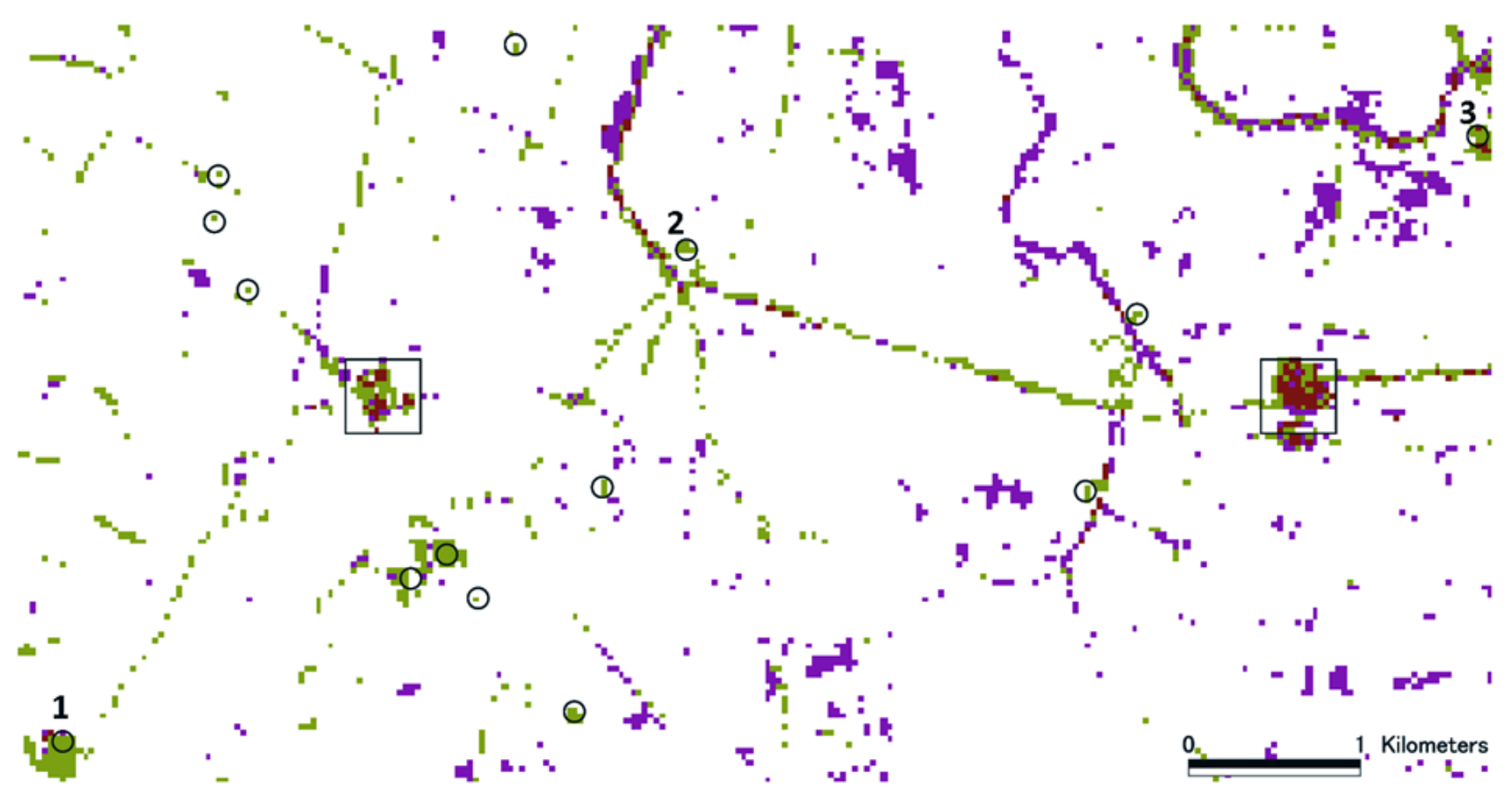

Figure 6. Testing area. Landsat 7 ETM+ Principal Component Analysis 4 and linear lookup method.

\section{RESULTS}

Remote sensing was successfully used in the determination of subsurface ancient sites at the humid region. Remote sensing provides significant advantages in the archeological researches in terms of efficiency, time and cost. Remote sensing and Geographical Information System help to especially understand the geomorphological structure in the region, prehistorical settlement structures and distribution a better way. There are many remote sensing products that can be used in archaeological applications.

In Landsat 7-ETM+ image, it was seen that the sites have a higher reflection value at the visible region in 4, 3, 2 bands and near-infrared (NIR) band 4 yielded a different reflection value different from other surface objects. Band 4 near-infrared (NIR) imagery has been successfully used to identify ancient sites. In the image analysis procedures, the use of near-infrared (NIR) and panchromatic band 8 yielded positive results. In Landsat 7 ETM+ images, the sites and completely destructed sites were determined in both visual perception and spectral analysis. The central part of destructed sites may have been determined in the satellite images. The modern settlements and sites which yielded close reflection values may be distinguished as spectral. In this paper, 42 unit unknown sites were determined except for the sites which were known but got lost due to destructed (Figure 3).

\section{REFERENCES}

Beck, A. (2007). Archaeological site detection: the importance of contrast. Proceedings of the 2007 Annual Conference of the Remote Sensing and Photogrammetry Society, Newcastle University, 11-14.

Chase, A. F., Chase, D. Z., Fisher, C. T., Leisz, S. J. \& Weishampel, J. F. (2012). Geospatial revolution and remote sensing LiDAR in Mesoamerican archaeology. PNAS, 109 (32), 12916-12921.

Corrie, R. K. (2011). Detection of ancient Egyptian archaeological sites using satellite remote sensing and digital image processing. Earth Resources and Environmental Remote Sensing/GIS Applications II, 1-19.

Drzewiecki, M. \& Raczkowski, W. (2008). Following O.G.S. Crawford satellite images and field archaeology in Sudan, Advances on Remote Sensing for Archaeology and Cultural Heritage Management, Proceedings of the 1st International EARSeL Workshop CNR, 3-6.

Etaya, M., Sudo, N. \& Sakata, T. (2000). Detection of subsurface ancient Egyptian remains utilizing optical and microwave satellite data, IGARSS 2000. IEEE 2000 International Geoscience and Remote Sensing Symposium. Taking the Pulse of the Planet: The Role of Remote Sensing in Managing the Environment. USA, 2480-2482, doi: 10.1109/IGARSS.2000.859613.

Fernandez-Diaz, J.C., Carter, W.E., Shrestha, R. L. \& Glennie, C. L. (2014). Now You See It... Now You Don't: Understanding Airborne Mapping LiDAR Collection and Data Product Generation for 
Archaeological Research in Mesoamerica. Remote Sensing, 6, 9951-10001.

Fiz, I., Subias, E. \& Cuesta, R. (2012). Deconstructing and Reconstructing the Landscape of Oxyrhynchus Using Textual Sources, Cartography, Remote Sensing and GIS, Thinking beyond the Tool Archaeological computing and the interpretive process, (Edited by Angeliki Chrysanthi, Patricia Murrieta Flores, Constantinos Papadopoulos), BAR International Series 2344, 131-154.

Golden, C., Murtha, T., Cook, B., Shaffer, D. S., Schroder, W., Hermitt, E. J. \& Scherer, A. K. (2016). Reanalyzing environmental lidar data for archaeology: Mesoamerican applications and implications. Journal of Archaeological Science: Reports, 9, 293-308.

Jensen, J.R. (2005). Introductory to Digital Image Processing: A Remote Sensing Perspective, Third Edition, Prentice Hall, 266-285.

Kumar, M. (2004). Digital Image Processing, Satellite Remote Sensing and GIS Applications in Agricultural Meteorology, Proceedings of the Training Workshop 7-11 July, 2003, Dehra Dun, India, 81-102.

Kvamme, K. L. (2005). Handbook of Archaeological Methods (Terrestrial Remote Sensing in Archaeology) [M]. Lanham, MA: AltaMira Press.
Lasaponara, R. \& Masini, N. (2013). Remote Sensing in Archaeology: An Overview, Journal of Aeronautics and Space Technologies 6 (1), 7-17.

Lillesand, T.M. \& Kiefer, R.W. (2000). Remote Sensing and Image Interpretation. John Wiley \& Sons, New York.

Opitz, R. S., Ryzewski, K., Cherry, J. F. \& Moloney, B. (2015). Using Airborne LiDAR Survey to explore Historic-era archaeological landscapes of Montserrat in the Eastern Caribbean, Journal of Field Archaeology, 40 (5), 523-541.

Parcak, S. (2007). Satellite remote sensing methods for monitoring archaeological tells in the Middle East. Journal of Field Archaeology, 32, 65-81.

Seton-Williams, M. V. (1954). Cilician Survey, Anatolian Studies 4, 121-174.

Ur, J. A. (2003). Corona satellite photography and ancient road networks: a northern Mesopotamian case study, Antiquity, 77 (295), 102-115.

Wilkinson, T. J. (2002). Archaeological survey of the Tell Beydar region, Syria, 1997: A preliminary report, In Van Lerberghe, K., Voet, G. (eds.), Tell Beydar Environmental and Technical Studies., Subartu 6, Turnhout, 1-37. 